\title{
The effect of an elevated fat level and feed protein concentrate on nutrient utilization and carcass quality of broiler chickens
}

\author{
W. Korol', G. Bielecka', T. Jaśkiewicz ${ }^{2}$ and S. Matyka ${ }^{1,2}$ \\ 'Central Laboratory of Feed Industry \\ Chmielna 2, 20-079 Lublin, Poland \\ ${ }^{2}$ Lublin Agricultural University, \\ Department of Biological Bases of Food and Feed Technology \\ Doświadczalna 48, 20-238 Lublin. Poland
}

(Received 17 January 2001; accepted 7 August 2001)

\begin{abstract}
Ninety-six Hybro broiler chickens were fed diets with increasing protein and energy contents at a constant protein-to-energy ratio: with no added fat (I, control), with $5 \%$ added fat (II), $9 \%$ (starter) and $10 \%$ (grower) added fat (III), $6 \%$ (starter) and $8 \%$ (grower) added fat and instead of soyabean meal, fish meal and premix, $10 \%$ feed protein concentrate (FPC) made from a meat-and-bone meal (MBM) and supplemented with amino acids, vitamins, and minerals (IV). Increasing the protein and energy concentrations improved body weight gains by an average of $26.5 \%(\mathrm{P} \leq 0.0 \mathrm{l})$ and lowered feed intake per kilogram gain by $16.3 \%(\mathrm{P} \leq 0.01)$ in comparison with the performance of control chickens (I). The use of FPC (IV) reduced the final body weight of the chickens by $2.1 \%$ and increased feed consumption by $5.6 \%(\mathrm{P} \leq 0.05)$ in comparison with chickens fed diets with a similar protein and energy content (III). Both the apparent protein digestibility coefficient of the diet as well as nitrogen retention determined by the slaughter method were lower in group IV than in the other groups ( $\mathrm{P} \leq 0.05$ in both instances). The protein content in the body of chickens fed diets containing FPC (IV) was lower $(\mathrm{P} \leq 0.05)$ than in the remaining groups with a concomitant distinct tendency towards a higher fat content. The carcass dressing percentage of chickens fed fat-supplemented diets was higher than in control chickens $(\mathrm{P} \leq 0.05)$. The use of $\mathrm{FPC}$ reduced breast muscle palatability $(\mathrm{P} \leq 0.05)$.
\end{abstract}

KEY WORDS: broiler chickens, fat, protein concentrate, carcass 


\section{INTRODUCTION}

Fats are a useful source of energy and essential fatty acids in the dicts of broiler chickens, especially of hybrids with a high, genetically determined growth potential. They improve palatability, reduce dust and separation of feed components. The utilization of fat depends on its fatty acid composition, the composition of the feed mixture, and on the age of the birds (Matyka, 1981; Hulan et al., 1984; Ketels et al., 1987; Korol, 1989). In practice, standard compositions of animal fats and vegetable oils are used in feeds.

Feed makers often add animal protein in the form of meal-and-bone meals $(\mathrm{MBM})$ to broiler diets, especially since the cost of this protein is lower than soyabean protein. Feed protein concentrates (FPC) containing synthetic amino acids, vitamins, minerals, growth stimulators and coccidiostatics have been produced using MBMs for the purpose of on-site compounding of diets for pigs and poultry on farms. Sell (1996) and Wang and Parsons (1998, 1998a, b) have studied MBM in diets for broilers.

Increasingly demanding standards of safety are being imposed on feeds, choice of feed components, their nutritional and microbiological quality, especially in relation to animal fats and meals. Broiler producers are interested in purchasing feeds that do not contain animal meals. The objective of this study was to assess the effect of adding fat to feed mixes and increasing the protein level, among others by adding a feed protein concentrate (FPC), on rearing performance, nutrient utilization, slaughter analysis and meat quality indices of broiler chickens.

\section{MATERIAL AND METHODS}

The experiment was conducted on 96 one-day-old, sexed and individually marked Hybro broiler chickens divided into 4 groups of equal gender proportions. Each group comprised 4 subgroups of 6 birds each ( 3 hens, 3 roosters) maintained in cages for 46 days. The birds were fed starter and grower diets with increasing protein and energy levels but with a constant energy-protein ratio (starter, $0.59 \mathrm{MJ}$ and grower $0.66 \mathrm{MJ}$ per $1 \%$ of crude protein content). The amino acid, vitamin and trace element contents in the diets were adjusted to the energy level according to Poultry Feeding Standards (1996). The diets were compounded from wheat and maize meals, soyabean oilmeal, fish meal, with the addition of standardized fat containing 15\% linoleic acid (C 18:2, n-6) and $\alpha$-linolenic acid (C 18:3, n-3), and feed protein concentrate. The FPC used to replace premix, fish meal and part of the soyabean oilmeal, was made from MBM supplemented with amino acids, vitamins, minerals, a coccidiostatic and growth stimulator (Table 1). The following diets were fed to groups: 


$$
\begin{aligned}
& \text { I - no added fat (control) } \\
& \text { II }-5 \% \text { added fat } \\
& \text { III }-9 \% \text { (starter) and } 10 \% \text { (grower) added fat } \\
& \text { IV }-10 \% \mathrm{FPC} \text { and } 6 \% \text { (starter) and } 8 \% \text { (grower) added fat. }
\end{aligned}
$$

On days 21 and 46 of rearing, the chickens were weighed, feed utilization per unit of growth and mortality were determined. The European efficiency ratio, EIB (Smulikowska, 1998), was calculated.

Digestibility experiments were conducted using the balance method in the third (starter) and sixth (grower) week of rearing. Excrements were collected for 4 days. The apparent digestibility of dry matter, crude protein, fat, and $\mathrm{N}$-free extractives was determined. The apparent metabolizable energy value adjusted to zero nitrogen retention $\left(\mathrm{AME}_{\mathrm{N}}\right.$ ) was calculated on the basis of these results.

After completion of the experiment, the chickens were subjected to a $12 \mathrm{~h}$ fast, then two hens and two roosters from each group were slaughtered and carcass dressing analysis conducted. The carcass dressing percentage with giblets, percentage of breast muscle without skin, thigh muscle without skin and bones, and abdominal fat were determined. The percentage of the neck, wings and back along with skin and bones in the carcass was estimated.

Nitrogen and metabolizable energy retention were determined by the slaughter method (Znaniecka et al., 1972). Four birds from each group ( 2 hens and 2 roosters) were slaughtered at the age of six weeks and then autoclaved in hermetically sealed containers with a known amount of water, at a pressure of $1.2 \mathrm{~atm}$. for 4 to $6 \mathrm{~h}$. After autoclaving, the material was comminuted and dried. The chemical composition of this material was the basis for determining the energy value of the body of broiler chickens assuming that $1 \mathrm{~g}$ of protein has a calorific value of $5.57 \mathrm{kcal}$, and $1 \mathrm{~g}$ of fat, $9.24 \mathrm{kcal}$. The content of other basic components, water, protein, fat and ash, was also determined (Znaniecka, 1969).

Dry matter, crude protein ( $\mathrm{N} \times 6.25$ ), crude fat, crude fibre, and ash in the diets and in samples after autoclaving were determined by conventional methods. $\mathrm{Ni}$ trogen in undigested protein in excrements was determined using the uranyl acetate method (Hartfiel, 1961), and fat after extraction with 10\% acetic acid in ethyl ether (March and MacMillan, 1979). The fatty acid composition of standardized fat mixtures was determined by gas chromatography after esterification of fatty acids with methanol in the presence of boron fluoride (Matyka, 1976). Taste panel evaluation of breast muscle was performed in compliance with Polish Standard PN-64/A-04022. Juiciness, tenderness, and palatability of the meat and aroma of bouillon were evaluated. Each parameter was assessed on a 5-point scale by an 11-member panel ( 5 points was the best possible score).

The results were subjected to analysis of variance; the significance of differences between averages was evaluated by Duncan's test. 
TABLE 1

Composition of mixtures, $\mathrm{g} / \mathrm{kg}$

\begin{tabular}{|c|c|c|c|c|c|c|c|c|}
\hline \multirow{2}{*}{ Ingredients } & \multicolumn{4}{|c|}{ Starter } & \multicolumn{4}{|c|}{ Grower } \\
\hline & 1 & II & II! & IV & I & II & III & IV \\
\hline Wheat & 709 & 357 & 268 & 367 & 780 & 468 & 327 & 401 \\
\hline Maize & - & 200 & 200 & 200 & - & 200 & 200 & 200 \\
\hline Soyabean oilmeal & 196 & 294 & 340 & 268 & 157 & 216 & 304 & 214 \\
\hline Milk powder & 30 & 30 & 30 & - & - & - & - & - \\
\hline Fish meal & 30 & 30 & 30 & - & 30 & 30 & 30 & - \\
\hline $\mathrm{FPC}^{1}$ & - & - & $\cdot$ & 100 & - & - & - & 100 \\
\hline Fat $^{2}$ & - & 50 & 90 & 60 & - & 50 & 100 & 80 \\
\hline $\mathrm{NaCl}$ & 3 & 3 & 3 & - & 3 & 3 & 3 & - \\
\hline Dicalcium phosphate & 11 & 12 & 13 & - & 10 & 11 & 12 & - \\
\hline Limestone & 11 & 12 & 13 & 5 & 10 & 11 & 12 & 5 \\
\hline Premix starter $^{3}$ & 10 & 12 & 13 & - & . & - & - & - \\
\hline Premix grower ${ }^{3}$ & - & - & - & - & 10 & 11 & 12 & - \\
\hline \multicolumn{9}{|l|}{ Estimated } \\
\hline crude protein & 191.9 & 217.0 & 227.0 & 228.0 & 175.0 & 198.0 & 207.0 & 206.0 \\
\hline ether extract & 25.0 & 82.0 & 110.0 & 84.0 & 24.0 & 84.0 & 122.0 & 116.0 \\
\hline crude fibre & 32.0 & 33.0 & 36.0 & 31.0 & 32.0 & 37.0 & 34.0 & 27.0 \\
\hline $\mathrm{N}$-free extractives & 587.0 & 498.0 & 461.0 & 496.0 & 579.0 & 505.0 & 457.0 & 479.0 \\
\hline \multicolumn{9}{|l|}{$\begin{array}{l}\text { Calculated } \\
\text { metabolizable }\end{array}$} \\
\hline energy, $\mathrm{MJ} / \mathrm{kg}$ & 11.6 & 12.6 & 13.3 & 13.3 & 11.6 & 12.7 & 13.6 & 13.8 \\
\hline lysine & 9.8 & 11.7 & 12.6 & 13.0 & 8.7 & 9.2 & 11.1 & 11.7 \\
\hline methionine & 4.2 & 4.7 & 5.0 & 5.2 & 3.9 & 4.2 & 4.6 & 4.9 \\
\hline vit. A, IU/kg & 8100 & 9700 & 10700 & 12100 & 7100 & 8500 & 9200 & 10100 \\
\hline vit. E, $\mathrm{mg} / \mathrm{kg}$ & 22 & 23 & 23 & 31 & 23 & 24 & 24 & 26 \\
\hline $\mathrm{Ca}, \mathrm{g} / \mathrm{kg}$ & 9.2 & 9.9 & 10.5 & 10.1 & 8.0 & 8.8 & 9.5 & 9.9 \\
\hline $\mathrm{P}, \mathrm{g} / \mathrm{kg}$ & 6.8 & 7.1 & 7.2 & 7.0 & 6.3 & 6.4 & 6.7 & 6.9 \\
\hline
\end{tabular}

1 protein concentrate, starter $S$ and grower $G$ with meat-and-bone meal: $\mathrm{AME}_{\mathrm{N}} 8.80$ and $8.35 \mathrm{MJ}$, protein $500 \mathrm{~g}$, lysine $40 \mathrm{~g}$, methionine $25 \mathrm{~g}$, Ca $70 \mathrm{~g}, \mathrm{P} 35 \mathrm{~g}, \mathrm{Na} 10 \mathrm{~g}$, vit. A 120000 and $100000 \mathrm{IU}$; (in mg): vit. E 200 and 150 , vit. $K 30$ and 20 , vit. $B_{1} 20$ and 10 , vit. $B_{2} 60$ and 40 , vit. $B_{6} 20$ and 0 , vit. $B_{12} 0,15$ and 0,12 , biotin 0,5 and 0,4 , folic acid 10 and 10 , panthotenic acid 120 and 100 , niacin 200 and 150 , choline 2000 and 1500 , Mn 650 and 600, Zn 500 and 400, Fe 200 and 150, Cu 60 and 40, J 5 and 4, Se 1 and $1 \mathrm{mg}$, Co 2.0 and 1.5 and growth promotor and coccidiostatic, respectively

2 standardized fat mixture, 15\% unsaturated fatty acids, rape seed oil and waste fat (1:2). In \%: linoleic acid $11.19, \alpha$-linolenic acid 4.87 , water 0.39 , acid value 30.5 and peroxide value 5.2

${ }^{3}$ in I kg of starter and grower premixes, respectively: vit. A 800000 and $700000 \mathrm{lU}$; in mg: vit. E 1000 and 1000 , vit. $K 200$ and 100 , vit. $B_{1} 100$ and 100 , vit. $B_{2} 400$ and 400 , vit. $B_{6} 40$ and 30 , vit. $B_{12} 1.5$ and 1.0 , biotin 5 and 0 , folic acid 20 and 20 , panthotenic acid 800 and 300 , niacin 1200 and 1000 , choline 2000 and 1500 ; methionine 100 and $100 \mathrm{~g}$; in $\mathrm{mg}$ : Mn 5000 and 5000, $\mathrm{Zn} 3000$ and 300, J 30 and 20, Se 10 and 20, Co 40 and 30 and growth promotor and coccidiostatic 


\section{RESULTS AND DISCUSSION}

Adding fat to rations with a proportionate increase in the level of amino acids, vitamins and trace elements, caused a positive and highly significant difference in the body weight of broiler chickens ( $\mathrm{P} \leq 0.01$; Table 2 ). Among the experimental groups II and III, in the first period of rearing, the chickens fed diets with a lower fat content achieved higher body weights; in the final period of rearing, the chickens fed diets with the highest fat content (III) achieved the highest body weights. The negative effect of a high fat content on the growth of young birds may result from their limited ability to digest this nutrient. This is why Larbier and Leclercq (1995) recommend that the share of fat in starter diets for broiler chickens does not exceed $5 \%$.

The differences in body weight corresponded with feed consumption per unit weight gain, which was an average $16.1 \%$ lower in chickens fed only fat-supplemented rations in comparison with the control group ( $\mathrm{P} \leq 0.01$; Table 2$)$. Within the experimental groups, feed intake was inversely proportional to its energy content. The EIB indicator equaled 238 in the experimental groups and was 53.5\% higher than in the control group, with the highest ratio being found in group III (255), which is $64.5 \%$ higher than in the controls (155). The feeding system used allowed the broilers to achieve their genetically high growth potential.

The results of the digestibility experiments indicate that the fat in all experimental diets had a higher apparent digestibility than the lipid fraction in the control group ( $\mathrm{P} \leq 0.01$; Table 3 ). The apparent digestibility coefficients of protein were lowest in group IV, in which the chickens were fed diets containing FPC, compris-

TABLE 2

Indices of broiler performance, $\mathrm{kg}$

\begin{tabular}{|c|c|c|c|c|c|c|}
\hline \multirow{3}{*}{$\begin{array}{l}\text { Groups, } \\
\text { fat and FPC supplement }\end{array}$} & \multicolumn{2}{|c|}{ Body weight, $g$} & \multicolumn{2}{|c|}{$\begin{array}{c}\text { Feed intake } \mathrm{kg} / \mathrm{kg} \\
\text { body weight }\end{array}$} & Losses, $\%$ & EIB \\
\hline & \multicolumn{2}{|c|}{ days } & \multicolumn{2}{|c|}{ days } & days & days \\
\hline & 21 & 46 & $0-21$ & $0-46$ & $0-46$ & $0-46$ \\
\hline I without supplement & $571^{\mathrm{B}}$ & $1793^{\mathrm{B}}$ & $1.83^{\mathrm{A}}$ & $2.30^{\mathrm{A}}$ & 8.3 & 155 \\
\hline II $5 \%(\mathrm{~S})$ and $5 \%(\mathrm{G})$ fat & $696^{\mathrm{A}}$ & $2177^{\mathrm{A}}$ & $1.58^{\mathrm{B}}$ & $2.03^{\mathrm{B}}$ & 4.2 & 223 \\
\hline III $9 \%(\mathrm{~S})$ and $10 \%(\mathrm{G})$ fat & $676^{A}$ & $2338^{\wedge}$ & $1.52^{\mathrm{B}}$ & $1.83^{\mathrm{c}}$ & 8.3 & 255 \\
\hline $\begin{array}{l}\text { IV } 6 \%(\mathrm{~S}) \text { and } 8 \%(\mathrm{G}) \text { fat } \\
\text { and } 10 \% \mathrm{FPC}\end{array}$ & $725^{\wedge}$ & $2290^{\wedge}$ & $1.58^{\mathrm{B}}$ & $1.93^{\mathrm{BC}}$ & 8.3 & 237 \\
\hline SEM & 17 & 59 & 0.037 & 0.035 & - & - \\
\hline
\end{tabular}

$\mathrm{S}$ - starter mixture, $\mathrm{G}$ - grower mixture

EIB (European efficiency ratio) $=100 \times \frac{\text { body weight }(\mathrm{kg}) \times \text { survival rate }(\%)}{\text { age }(\text { days }) \times \mathrm{FCR}(\mathrm{kg} / \mathrm{kg})}$ 
TABLE 3

Apparent digestibility coefficiens of nutrients, \%

\begin{tabular}{|c|c|c|c|c|c|}
\hline $\begin{array}{l}\text { Groups, } \\
\text { fat and FPC supplement }\end{array}$ & $\begin{array}{c}\text { Dry } \\
\text { matter }\end{array}$ & $\begin{array}{l}\text { Crude } \\
\text { protein }\end{array}$ & $\begin{array}{c}\text { Ether } \\
\text { extract }\end{array}$ & $\begin{array}{l}\mathrm{N} \text {-free } \\
\text { extractives }\end{array}$ & $\begin{array}{l}\text { Calculated } \\
\mathrm{ME}, \mathrm{MJ} / \mathrm{kg}\end{array}$ \\
\hline \multicolumn{6}{|l|}{ Starter diets } \\
\hline I without supplement & 67.7 & $84.4^{a b}$ & $59.9^{13}$ & 76.3 & 11.2 \\
\hline Il $5 \%(S)$ fat & 67.4 & $85.0^{\mathrm{a}}$ & $84.9^{\wedge}$ & 75.3 & 12.5 \\
\hline III $9 \%(S)$ fat & 68.7 & $85.2^{a}$ & $83.3^{\wedge}$ & 76.1 & 13.0 \\
\hline IV $6 \%(\mathrm{~S})$ fat and $10 \% \mathrm{FPC}$ & 68.1 & $83.2^{\mathrm{b}}$ & $85.2^{\wedge}$ & 76.4 & 12.7 \\
\hline SEM & 1.04 & 0.53 & 2.02 & 1.18 & - \\
\hline \multicolumn{6}{|l|}{ Grower diets } \\
\hline 1 without supplement & 73.6 & $84.4^{\mathrm{b}}$ & $63.2^{\mathrm{B}}$ & $82.6^{\prime \prime}$ & 11.5 \\
\hline $115 \%(G)$ fat & 71.8 & $83.4^{\mathrm{ab}}$ & $85.2^{\wedge}$ & $80.4^{\mathrm{bb}}$ & 12.7 \\
\hline III $10 \%(\mathrm{G})$ fat & 73.2 & $86.1^{a}$ & $86.3^{\wedge}$ & $79.6^{\mathrm{b}}$ & 13.6 \\
\hline IV $8 \%(\mathrm{G})$ fat and $10 \% \mathrm{FPC}$ & 72.0 & $83.1^{\mathrm{b}}$ & $86.4^{\mathrm{A}}$ & $78.1^{\mathrm{b}}$ & 13.5 \\
\hline SEM & 1.57 & 0.77 & 2.80 & 0.88 & - \\
\hline
\end{tabular}

$\mathrm{S}, \mathrm{G}-\mathrm{as}$ in Table 2

a.b $P \leq 0.05 ; \quad{ }^{A .13} \mathrm{P} \leq 0.01$

ing mainly MBM. The digestibility of protein in MBM is usually lower than in soyabean and fish meals (Larbier and Leclercq, 1995; Poultry Feeding Standards, 1996). The variability of MBM production conditions, mainly temperature, and various standards of selection of animal raw materials are why animal-derived meals are characterized by marked variability in their content of digestible amino acids (Wang and Parsons, 1998). The destructive effect of utilization processes on the biological value of MBM protein is confirmed by its low, average $63.6 \%$, content of available lysine in total lysine (Matyka et al., 1989). The observed tendency towards reduction of digestibility coefficients of $\mathrm{N}$-free extractives, especially when larger amounts of fat are added, may result from reduced activity of $\alpha$-amylase in the pancreas when fat-supplement diets are fed (Jamroz and Wertelecki, 1998). The calculated apparent metabolizable energy of the diets $\left(A M E_{N}\right)$ corresponded with the value estimated on the basis of tables, with the exception of $\mathrm{AME}_{\mathrm{N}}$ of the diets for group IV, which were from 0.33 to $0.63 \mathrm{MJ} / \mathrm{kg}$ lower than estimated.

As the protein and fat contents in the diets rose, so did nitrogen retention in the bodies of the birds ( $\mathrm{P} \leq 0.05$; Table 4 ). The exception was the chickens fed the diets containing FPC (IV). The protein digestibility of these diets was the lowest (Table 3) and its utilization was poorest, despite adjusting the total content of essential amino acids, methionine and lysine to the energy level (Table 1). Wang and Parsons (1998b) found that in rations containing MBM for broiler chickens, the content of digestible amino acids should be taken into account rather than total 
amino acid content. Moreover, they recommend supplementing MBM-containing diets for chickens with synthetic amino acids, especially when animal meals with low amino acid digestibility are used.

Adding fat to diets increased the fat content in the bodies of broilers $(\mathrm{P} \leq 0.01$; Table 5). The protein content in birds from group IV fed FPC-containing diets was the lowest among all of the experimental groups $(\mathrm{P} \leq 0.05)$. Despite differences in the protein and fat contents in the bodics of birds in relation to pre-slaughter weight, the basic chemical composition of breast muscle expressed by the content of water, protein, fat and ash, was independent of the dietary variants (Table 6).

The carcass dressing percentage of the chickens in the experimental groups fed diets with added fat was significantly higher (77.4-77.7\%) than of control birds $(75.9 \%)(\mathrm{P} \leq 0.05$; Table 7$)$. The percentage of muscles in the carcass, $41.2 \%$ on average, did not differ significantly among groups. The abdominal fat content in the carcass ranged from 2.71 to $4.00 \%$ among groups, with no significant differences, despite the highly significant differences in adiposity depending on the diet (Table 5). Abdominal fat content may not be a sufficiently sensitive indicator of broiler carcass adiposity, especially given the small number of birds subjected

TABLE 4

Nitrogen and energy retention, $\%$

\begin{tabular}{lcc}
\hline $\begin{array}{l}\text { Groups, } \\
\text { fat and FPC supplement }\end{array}$ & N-retention & $\begin{array}{c}\text { Metabolizable } \\
\text { energy retention }\end{array}$ \\
\hline I without supplement & $41.0^{\mathrm{b}}$ & $33.6^{\mathrm{b}}$ \\
II $5 \%(\mathrm{~S})$ and $5 \%(\mathrm{G})$ fat & $42.4^{\mathrm{b}}$ & $38.1^{\mathrm{b}}$ \\
III $9 \%(\mathrm{~S})$ and $10 \%(\mathrm{G})$ fat & $46.9^{\mathrm{a}}$ & $41.5^{\mathrm{a}}$ \\
IV $6 \%(\mathrm{~S})$ and $8 \%(\mathrm{G})$ fat and 10\% FPC & $40.6^{\mathrm{b}}$ & $39.3^{\mathrm{ab}}$ \\
SEM & 1.41 & 1.15 \\
\hline
\end{tabular}

$\mathrm{S}, \mathrm{G}-\mathrm{as}$ in Table 2

a.b $\mathrm{P} \leq 0.05$

TABLE 5

Chemical composition of pre-slaughter body weight

\begin{tabular}{lcccc}
\hline Groups, fat and FPC supplement & Water & Protein & Fat & Ash \\
\hline I without supplement & 679.0 & $166.0^{\mathrm{ab}}$ & $121.4^{\mathrm{as}}$ & $25.9^{\mathrm{ab}}$ \\
II 5\%(S) and 5\%(G) fat & 643.3 & $180.4^{\mathrm{a}}$ & $144.3^{\mathrm{Ab}}$ & $28.0^{\mathrm{a}}$ \\
III 9\%(S) and 10\%(G) fat & 632.4 & $180.0^{\mathrm{a}}$ & $152.5^{\mathrm{Aa}}$ & $26.4^{\mathrm{ab}}$ \\
IV 6\% (S) and 8\%(G) fat and 10\% FPC & 646.4 & $161.5^{\mathrm{b}}$ & $160.3^{\mathrm{a}}$ & $24.8^{\mathrm{b}}$ \\
SEM & 22.8 & 5.6 & 4.1 & 1.4 \\
\hline
\end{tabular}

$\mathrm{S}, \mathrm{G}-\mathrm{as}$ in Table 2

a.b $\mathrm{P} \leq 0.05$ 
TABLE 6

Chemical composition of breast muscles, $\mathrm{g} / \mathrm{kg}$

\begin{tabular}{lcccc}
\hline Groups, fat and FPC supplement & Water & Protein & Fat & Ash \\
\hline I without supplement & 731 & 226 & 26.8 & 10.0 \\
II $5 \%(\mathrm{~S})$ and $5 \%(\mathrm{G})$ fat & 732 & 221 & 30.2 & 10.0 \\
III 9\% (S) and 10\%(G) fat & 736 & 224 & 26.8 & 10.3 \\
IV 6\% (S) and 8\% (G) fat and 10\% FPC & 730 & 224 & 32.0 & 10.3 \\
SEM & 9.9 & 6.8 & 7.6 & 0.7 \\
\hline
\end{tabular}

$\mathrm{S}, \mathrm{G}-$ as in Table 2

TABLEA 7

Slaughter analysis

\begin{tabular}{cccccccccc}
\hline Group & $\begin{array}{c}\text { Dressing } \\
\text { percentage } \\
\text { with giblets }\end{array}$ & $\begin{array}{c}\text { breast } \\
\text { muscles }\end{array}$ & $\begin{array}{c}\text { leg } \\
\text { muscles }\end{array}$ & neck & wings & $\begin{array}{c}\text { skin with } \\
\text { subcutaneous } \\
\text { fat }\end{array}$ & $\begin{array}{c}\text { abdominal } \\
\text { fat }\end{array}$ & rest' $^{\prime}$ \\
\hline I & $75.9^{\text {h }}$ & 20.8 & 21.3 & 5.5 & 10.5 & 8.3 & 2.7 & 30.9 \\
II & $77.7^{\text {a }}$ & 19.6 & 20.8 & 5.9 & 10.6 & 8.6 & 3.3 & 31.2 \\
III & $77.6^{\text {a }}$ & 20.3 & 20.8 & 6.0 & 10.3 & 8.8 & 4.0 & 29.8 \\
IV & $77.4^{\text {ab }}$ & 20.2 & 21.0 & 5.5 & 10.4 & 9.7 & 3.6 & 29.6 \\
SEM & 0.36 & 0.76 & 0.63 & 0.59 & 0.31 & 0.85 & 0.86 & 0.81 \\
\hline
\end{tabular}

1 skelet with back and pelvis muscles and leg bones

a.b $-\mathrm{P} \leq 0.05$

to dissection. The ratio of linoleic (n-6) to $\alpha$-linolenic $(n-3)$ acids in the standardized fat was $2.3(\mathrm{w} / \mathrm{w})$. A similar proportion of these acids was maintained in the fat of the broilers (Korol and Matyka, 2000). Wood and Enser (1997) recommend that the ratio of $n: 6$ to $n: 3$ acids in animal-derived foods does not exceed 4 .

The feed diets used in this experiment did not significantly affect the aroma or tenderness of the breast muscle of the chickens, as evaluated by a taste panel using a point scale (Table 8). Feeding chickens fat-supplemented diets led to a significant reduction of the juiciness of breast muscles, but did not affect their palatability. The palatability of the breast muscles of chickens from group IV fed diets with an MBM-containing concentrate was significantly lower than in the remaining groups $(\mathrm{P} \leq 0.05)$. These results point to the possible negative impact of $\mathrm{MBM}$ on the taste qualities of poultry carcasses. 
TABLE 8

Sensory evaluation of bouillon and breast muscles ( 5 points scale)

\begin{tabular}{|c|c|c|c|c|c|}
\hline \multirow{2}{*}{$\begin{array}{l}\text { Groups, } \\
\text { fat and FPC supplement }\end{array}$} & \multicolumn{2}{|c|}{ Bouillon aroma } & \multicolumn{3}{|c|}{ Breast muscles } \\
\hline & intensity & desirability & juiciness & tenderness & palatability \\
\hline I without supplement & $4.38^{\prime \prime}$ & 4.27 & $4.68^{a}$ & 4.62 & $4.68^{a}$ \\
\hline II $5 \%(\mathrm{~S})$ and $5 \%(\mathrm{G})$ fat & $4.20^{\circ}$ & 4.07 & $4.14^{\mathrm{b}}$ & 4.36 & $4.18^{\mathrm{a}}$ \\
\hline III $9 \%(\mathrm{~S})$ and $10 \%(\mathrm{G})$ fat & $4.22^{a b}$ & 4.11 & $4.2 \mathrm{l}^{\mathrm{b}}$ & 4.39 & $4.43^{-}$ \\
\hline $\begin{array}{l}\text { IV } 6 \%(\mathrm{~S}) \text { and } 8 \%(\mathrm{G}) \text { fat } \\
\text { and } 10 \% \mathrm{FPC}\end{array}$ & $4.27^{\mathrm{ab}}$ & 4.03 & $4.23^{\mathrm{b}}$ & 4.37 & $3.82^{\mathrm{b}}$ \\
\hline SEM & 0.07 & 0.10 & 0.14 & 0.27 & 0.17 \\
\hline
\end{tabular}

$\mathrm{S}, \mathrm{G}$ as in Table 2

a.b $\mathrm{P} \leq 0.05$

\section{CONCLUSIONS}

Adding fat to diets for Hybro broilers while maintaining a constant energyprotein ratio and adjusting nutrients to the energy level, led to a highly significant improvement in rearing performance. Chickens fed diets containing MBM, however, achieved a $2.1 \%$ lower final body weight and showed $5.6 \%$ poorer feed utilization in comparison with birds fed diets with a similar protein and energy content, in which in addition to soyabean oilmeal, fish meal was the other source of protein. The chemical body composition of broilers changed depending on the diet. The body protein content of broilers fed diets containing MBM was lower than in the remaining groups, while their fat content was higher. The results of this study confirm that protein digestibility may be lowered in diets containing FPC with MBM, while concomitantly pointing to the need to take into consideration the content of digestible amino acids in animal meals. Feeding diets prepared using FPC led to a deterioration of taste panel evaluation of the breast muscle of these chickens, especially of palatability. Using MBM in broiler nutrition may cause a deterioration of the organoleptic qualities of broiler carcasses.

\section{REFERENCES}

Hartfiel W., 1961. Zur Bewertung von Futtermitteln in Tierversuch mit Hähnchen. III. Vergleichend Untersuchungen zur chemischen Trennug von Kot - und Urin Stickstoff in Hahnenexkrementen sowie eine Modification der Uranylacetal Methode. Arch. Geflügelk. 25, 469-475

Hulan H.W., Proudfoot F.G., Nash D.M., 1984. The effects of different dietary fat sources on general performance and carcass fatty acid composition of broiler chickens. Poultry Sci. 63, 324-332 


\section{FAT LEVEL AND PROTEIN CONCENTRATE IN DIETS FOR CHICKENS}

Jamroz D., Wertelecki T., 1998. Influence of fat addition to feed mixtures on the rate of yolk sac resorption in chickens, blood and pancreas enzyme activity. J. Anim. Feed Sci. 7, Suppl. 1, $271-276$

Ketels E., Groote De G., 1987. Effects of fat source and level of fat inclusion on the utilization of fatty acid in broiler diets. Arch. Geflügelk. 51, 27-32

Korol W., 1989. Studies on the influence of fatty acid composition of diets on nutrients digestibility and some indicators of the lipid metabolism in broiler chicks (in Polish). PhD. Thesis, Lublin Agricultural University, Lublin (Poland)

Korol W., Matyka S., 2000. Influence of fat standardization on fatty acid profile of abdominal fat in broiler chicks (in Polish). Biul. nauk. Przem. Pasz. 39 (1/4), 15-22

Larbier M., Leclereq B., 1995. Poultry Nutrition (Polish Edition). PWN, Warszawa (Poland), pp. 276-277

March B.E., MacMillan C., 1979. Excrection of soap falty acids by chicks fed diets of different composition. Poultry Sci. 58, 1246-1249

Matyka S., 1976. A routine method for the determination of fatty acids content in mixed feeds and feed components (in Polish). Biul. inf. Przem. Pasz. 15 (2), 38-46

Matyka S., 1981. Feeding utility of some highly rancid animal fats for broiler chicks (in Polish). Editor: Central Laboratory of Feed Industry, Lublin (Poland)

Matyka S., Bartuzi G., Jaśkiewicz T., Korol W., 1989. Chemical composition of meat and bone meals (in Polish). Rocz. Nauk. Zoot. 16 (2), 157-167

Polish Standard PN-64/A-04022. Methods of Sensoric Analysis. Analysis of Particular Characteristics and Over-All Quality by Scoring Methods. Principles of the Construction of Scoring Models for Individual Food Products (in Polish)

Poultry Feeding Standards. Feeding Recommendation and Nutritive Value of Feed (in Polish). 1996. Editor: The Kielanowski Institute of Animal Physiology and Nutrition, Jabłonna (Poland)

Scll J.L., 1996. Influence of dietary concentration and source of meat and bone meal on performance of turkey. Poultry Sci. 75, 1076-1079

Smulikowska S., 1998. Nutritive value of rye, triticale and wheat for poultry (in Polish). Editor: The Kielanowski Institute of Animal Physiology and Nutrition, Jabłonna (Poland)

Wang X., Parsons C.M., 1998. Effect of raw material source, processing systems, and processing temperatures on amino acid digestibility of meat and bone meal. Poultry Sci. 77, 834-841

Wang X., Parsons C.M., 1998a. Bioavailability of the digestible lysine and total sulfur amino acids in meat and bone meals varying in protein quality. Poultry Sci. 77, 1003-1009

Wang X., Parsons C.M., 1998b. Dietary formulation with meat and bone meal on a total versus a digestible or bioavailable amino acid basis. Poultry Sci. 77, 1010-1015

Wood D.J., Enser M., 1997. Factors influencing fatty acids in meat and role of antioxidants in improving meat quality. Brit. J. Nutr. 78, Suppl. 1, 49-60

Znaniecka G., 1969. Caloric value of protein and fat of the chicken's body. In: Energy Metabolism of Farm Animals. Oriel Press Ltd., pp. 407-408

Znaniecka G., Chomyszyn M., Frydrychewicz J., 1972. Nitrogen and cnergy retention in growing geese (in Polish). Rocz. Nauk rol. B-94 (3), 108-114 


\section{STRESZCZENIE}

Wplyw podwyższonej zawartości tluszczu i dodatku paszowego koncentratu białkowego w żywieniu kurcząt brojlerów na wykorzystanie skladników pokarmowych paszy oraz jakość tuszki

Dziewięćdziesiąt sześć kurcząt brojlerów Hybro żywiono mieszankami paszowymi o wzrastającej zawartości białka i energii oraz stałym stosunku energetyczno-białkowym: bez dodatku tłuszczu (I - kontrola), z 5 (II), 9 (starter) lub 10\% (grower) dodatkiem thuszczu (III), z 6 (starter) lub 8\% (grower) dodatkiem tłuszczu oraz $10 \%$ udziałem koncentratu białkowego zamiast śruty sojowej, mączki rybnej i premiksu, sporządzonego z mączki miçsno-kostnej (MMK) i uzupełnionego aminokwasami, witaminami i składnikami mineralnymi. Zwiększenie koncentracji białka i energii poprawilo, średnio o $26,5 \%(\mathrm{P} \leq 0,01)$, przyrosty masy ciała oraz obniżyło o $16,3 \%(\mathrm{P} \leq 0,01)$ zużycie paszy na jednostkę przyrostu, w porównaniu $z$ wynikami odchowu kurcząt kontrolnych (l). Zastosowanje

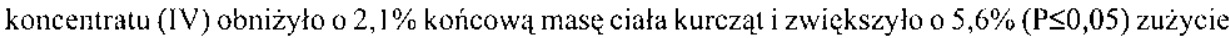
paszy w porównaniu z kurczętami żywionymi mieszankami o podobncj zawartości białka $\mathrm{i}$ energii (III). Również współczynniki strawności pozornej białka ( $\mathrm{P} \leq 0,05)$ mieszanek paszowych grupy IV oraz określona metodą ubojową retencja azotu $(P \leq 0,05)$ okazały się niższe od uzyskanych w pozostałych grupach ptaków. Zawartość białka w ciele ptaków żywionych mieszankami paszowymi z. koncentratem (IV) była mnicjsza $(P \leq 0,05)$ niż w pozostałych grupach przy jednoczesnej, wyrażnej tendencji wzrostu zawartości tłuszczu. Wydajność rzeźna kurcząt żywionych natłuszczonymi mieszankami paszowymi była wyższa niż kurcząt z grupy kontrolnej $(\mathrm{P} \leq 0,05)$. Zastosowanie koncentratu $z$ udziatem MMK obniżyło smakowitość mięśni piersiowych kurcząt $(\mathrm{P} \leq 0,05)$. 